\title{
Rural Tourism Sustainable Business Performance: Dynamic Capability Perspective
}

\author{
Sukaris ${ }^{1^{*}}$, Sri Hartini ${ }^{2}$, Dien Mardhiyah ${ }^{2}$, Hendra Suwardana ${ }^{3}$ and Heru \\ Baskoro $^{1}$ \\ ${ }^{1}$ Management Department, Faculty of Economics and Business, Universitas Muhammadiyah Gresik, Gresik \\ Regency, East Java, Indonesia \\ ${ }^{2}$ Dept. of Management, Faculty of Economics and Business, Universitas Airlangga, address: Street, Airlangga No.4 - 6, \\ Airlangga, Gubeng, City of Surabaya, East Java, 60115, Surabaya, Indonesia. \\ ${ }^{3}$ Universitas PGRI Ronggolawe, Tuban, Indonesia \\ *Corresponding author email: sukaris21@umg.ac.id
}

\begin{abstract}
Currently, Indonesia has a product portfolio of promising tourist destinations, especially rural tourism which has good potential in the future. Therefore, it is important for tourism managers to develop sustainable tourism in terms of performance, because thus managers have a complete understanding of performance rural tourism business. In terms of managing a sustainable tourism village, managers must realize the importance of dynamic capabilities as a measure of sustainable business performance. The research investigates the effect of dynamic capabilities on the performance of a rural tourism sustainable business. Hypotheses were tested with regression equations with WarpPls software. The results explain that the dynamic capability of the sensing dimension has an effect on the performance of sustainable tourism business, the dynamic capability of the seizing dimension has no effect on the performance of a sustainable tourism business and the dynamic capability of the reconfiguring dimension has no effect on the performance of sustainable tourism.
\end{abstract}

Keywords: Rural Tourism, Business, Dynamic Capability

\section{INTRODUCTION}

The growth of village tourism is significant and tends to continue. In recent years, based on BPS records, 1,734 tourist villages are scattered in each of the islands. Where the island of Java - Bali occupies the highest position with 857 tourist villages. Then followed by Sumatra as many as 355 villages, Nusa Tenggara 189 villages, Kalimantan 117 villages. In addition, Sulawesi Island also recorded 119 tourist villages, Papua 74 villages, and Maluku as many as 23 villages [1]. Therefore, it is important for tourism managers to develop sustainable tourism in terms of performance, because thus managers have a complete understanding of the performance of village tourism businesses. In terms of managing a sustainable tourism village, managers must realize the importance of dynamic capabilities as a measure of sustainable business performance. Indonesia currently has a promising portfolio of destination products, the portfolio of Indonesian destination products presented in relation to rural tourism is $3 \%$ of $60 \%$ cultural tourism, so this tourism also has quite good potential in sustainability in the future,

[2]WTO defines rural tourism as a tourism product "which gives visitors personalized contact, a sense of the rural physical and human environment and, to the extent possible, allows to participate in the activities, traditions and lifestyle of local communities. [3]summarizes some of the dimensions of village tourism which include the characteristics of the location, the purpose of the visit, attractions / activities, scale of operation and sustainability. The organization must find the best way to ensure that the activities carried out meet sustainability requirements. Two considerations should be given priority when defining sustainable business performance. first, business sustainability refers to $\mathrm{k}$ the ability of firms to generate profits to ensure long-term survival. second is that business sustainability is also related to the ability of an organization to provide products or services based on processes or technology that do not harm the environment or public health as a whole. In other words, one major outcome of a sustainability strategy is that the company will be able to stay in the market for longer by maximizing internal and external resources for the best financial results. [4]identify factors driving the performance of sustainable destinations 1) tourism and related infrastructure; (2) economic conditions; (3) security, safety and health; (4) tourism price competitiveness; (5) government policies; (6) environmental sustainability[5]; (7) workforce skills and training, and (8) natural and cultural resources. 
Until now, the tourism villages in district Gresik have been developed based on the consideration of economic development and village income and the development of tourism facilities and infrastructure has also been carried out, creating jobs and economic activities for the local community, there is public awareness of tourism potential. starting to grow, however, it still requires assistance from related parties (government or private), likewise to fulfill elements of sustainable development it also requires a sense of ownership, involvement, community participation and also involving as much local resources as possible. Even in the Regulation of the Minister of Tourism (Permen) No. 14/2016 on Guidelines for Sustainable Tourism Destinations which adopts the "Global Sustainable Tourism Council (GSTC) international standard, which considers three main aspects, namely environmental, social, and economic aspects for the present and future. This should also involve the 3P principles, namely People, Planet, Prosperity, or community empowerment, nature preservation, and welfare improvement. For this reason, one way to improve the sustainable business performance of village tourism is to increase the dynamic capabilities of village tourism managers. Previous research has linked dynamic capability to business performance, [6]Elements of Industry 4.0 such as big data, Internet of Things and smart factories have a positive role in promoting the application of information technology (IT), which contributes to sustainable business performance. other research ju have not related dynamic capability with business performance such as [7]-[10] However, this research was conducted on a profit business pure, while research conducted on social businesses and businesses was not widely carried out.

The specific objective of this study was to measure business performance sustainable(sustainability business performance)of village tourism from the perspective of the capabilities of dynamic(dynamic capabilities) tour manager villages in Gresik, urgency of this study was to determine the dynamic capabilities of the manager as the ability to integrate, build, and configure rework internal and external competencies to cope with rapidly changing environments by integrating, reconfiguring, acquiring and releasing resources - to match or even create market changes so that the developed tourism business has a sustainable performance.

\section{LITERATURE REVIEW}

The rapid Sustainable tourism itself is defined by the UNWTO as: "Tourism that fully takes into account the present and future economic, social and environmental impacts and responds to the needs of visitors, industry (tourism), the environment and host communities." That is, sustainable tourism makes the community the main actor in tourism businesses to move the wheels of regional tourism and get greater benefits. Sustainable tourism practices not only consume tourism resources but furthermore, sustainable tourism requires anyone who is involved in it to participate in observing the environment and culture that is included in tourism resources[11]

The concept of developing a tourism village is to make the village a tourism destination by combining natural and cultural tourist attractions, and public tourism facilities services, as well as access adequate mobility, with the ways and traditions of village community life.

The development of a tourism village is expected to provide (1) economic benefits, such as income and employment, (2) social benefits such as increased community skills, (3) environmental benefits such as improved infrastructure, and other benefits for the community. The government in the future will further promote the development of tourism villages, and invite all stakeholders to jointly succeed this program. The government will also complement the development of tourist villages with the preparation of destination, management and HR standards. The results are expected to be replicated in many other potential villages, in order to achieve common goals, namely improving the quality of the environment, community welfare, and preserving the culture of the people in tourism villages [12].

Strategic issues in sustainable tourism are as follows: 1) Increasing the responsibility of corporate stakeholders, 2) Producing suitable forms of tourism, 3) Sustaining of social and cultural resources, 4) Sustaining natural environment, 5) The need for effective plans for planning tourist destinations, 6) Role of carrying capacities and indicators in sustainable tourism, 7) Avoiding conflict. 8) Increasing community involvement, and 8) Direction for the future [13]

\subsection{Sustainable Business Performance Business}

The performance consists of the actual output of an organization as a whole, Business performance measurement by [6]. In this case it is measured by: 1) Profitability, in terms of net profit margin, ROI, 
profitability growth, and overall, financial performance. 2) Sales, in terms of sales achievement, sales growth and market share. And 3) Customer satisfaction, in terms of overall product quality, competitive price products, responsiveness, after-sales service, fast delivery times, and on-time delivery. [14]stated that maintaining sustainable performance means uniting, in a long-term vision, a balance of three dimensions: social, competitive and economic. Be more specific first; social social performance as an assessment of the level of satisfaction, trust and cohesion of stakeholders. That means: making optimal use of environmental resources and helping to conserve natural heritage and biodiversity; to respect the socio-cultural authenticity of the community; to preserve organizational well-being and protect workers from health and safety; etc. Second; Competitive refers to maintaining a high level of satisfaction with the needs of tourists, and ensuring a meaningful experience and consciously considering sustainable aspects. Third, economic performance as the linkage of economic benefits with all stakeholders, including stable employment and income opportunities for the community and profitability of tourism management organizations.

In the context of organizational performance and business entities that are influenced by dynamic capabilities, research by [15] has conducted research that there is an influence between dynamic capabilities and performance, dynamic capabilities are measured by sensing, seizing and reconfiguring. Research by [16] examines dynamic capabilities with Sensing Capability, Learning Capability, Integrating Capability, Alliance Management Capability, Reconfiguration Capability, Coordinating Capability, from the research results there is an influence between dynamic capabilities and the sustainable performance of small businesses. Research by [17] shows that sensing capabilities, seizing capabilities, and reconfiguration capabilities affect the performance of manufacturing companies in Kenya. However, other studies show different results such as research by [18] dynamic integration capability has no effect on performance, dynamic learning capability has no effect on performance and dynamic reconfiguration capability has no effect on performance.

\subsection{Dynamic Capability}

The term dynamic capabilities refers to the ability of the parts or units (organization) to carry out their activities in a reliable manner that is change-oriented [19]. The orientation of change in dynamic capabilities must also be based on the resources they have.

Dynamic capabilities can consist of three important dimensions that are interrelated, that is sensing, seizing and reconfiguring [20]

Activities in the dynamic capabilities dimension

- Sensing is the activity of scanning, seeking and exploring opportunities with the aim of gathering information and learning processes about markets, competitors and another external environment.

- Seizing includes activities on how to get or seize opportunities to mobilize resources and catch value, and renewal sustainable through a transformation. These activities may also include making decisions, developing shared understanding among relevant stakeholders, and formulating action plans to respond to identified opportunities.

- Reconfiguring is an activity that combines all resources and maximizes both internal and external resources which allows the company to maintain profitable growth.

Previous studies provide several important indicators of the dimensions of dynamic capabilities, including; [21] Sensing consists of observing developments, observing changes in people's values and lifestyles, looking for new opportunities in the operating environment, looking for new practices and conceptualizing new ways of doing business; Seizing consists of indicators of reacting to changes in the operating environment, actively developing new ways of doing business, continuing to build complementary knowledge and trying to actively influence the direction of the business sector whereas for reconfiguring it consists of knowledge acquired integrated with the organization, resources that are existing is used in new areas and in new purposes and existing knowledge is used in new areas. [22] provide several important indicators of dynamic capabilities including, sensing consisting of 1) The existence of participating in a professional manner, using an established process to identify target market segments, changing customer needs, and customer innovation, 2) Observing best practices in our sector, 3) Gathering economic information about operations and the operational environment. Seizing consists of 1) Investing in finding solutions for customers, 2) Adopting best practices 3) Responding to failures demonstrated by employees 4) Changing practices when customer feedback gives us reasons to change. Reconfiguring consists of 1) Implementing new types of 
management methods, 2) Frequently changing marketing methods or strategies, 3) Updating business processes substantially and 4) Constantly and substantially updating how to achieve targets and goals.

\section{MATERIAL AND METHODS}

The approach used in this study is a quantitative approach. The quantitative approach is used because with this approach the research process is carried out in a structured manner and uses research samples. The data source used in this study is primary data obtained through the results of collecting questionnaires to users of managers village tourism in Gresik Regency with using a Likert scale, the data collected is interval data. Meanwhile, secondary data used is only for preliminary data and has the character of supporting data obtained from articles in journals, literatures, and other references. The data collection technique used in this research is primary data collection techniques, namely data collected directly from respondents, in this case the manager, village tourism which consists of all BUMdes administrators who manage village tourism businesses and also tourism conscious group administrators who are also given authority by the village to managing village tours.

In answering the research objectives and assessing the developed model, the analysis technique used is the technical analysis of Structural Equation Modeling (SEM) using the WarpPLS software program.

\section{RESULTS AND DISCUSSION 4.1 Characteristics Of Respondents}

The study was conducted using respondents to be the sample with a total of 23 respondents who were used as research samples. The sample has been resampled (technique bootstrap) up to 300 samples. So that the data from the variables manifest in validity excluded from the latent variable gauge model. Each respondent is given a questionnaire to provide answers to the statements that have been provided. This study identifies the characteristics of respondents based on gender.

\subsection{Testing of Validity and Reliability}

Tests for the accuracy of the measurement scale or the validity of the data were carried out on the question items on variable dynamic capabilitysensing (DCS), dynamic capability-seizing (DCSZ), dynamic capability-reconfiguring (DCR), environmental dynamics during the Covid-19 pandemic (EDC). ) and sustainable tourism performance (SP). The measurement scale accuracy test carried out in this study includes the validity test and the reliability test, which are described as follows:

- Validity Test

The results of the first stage validity test show that all indicators have a value above 0.5 However, there are two items whose values are below 0.5 , namely SP_1 and LS7, for other question items or indicators used to measure each latent variable, they are able to measure what is to be measured or have met the convergent validity of an indicator. Likewise, the results of the comparison between loading and cross loading show that the loading value of all factors or indicators is greater than the cross loading, so the discriminant validity is fulfilled. This result is in accordance with the opinion of [23]. The accuracy of the measurement scale is a condition that must be met so that further testing can be carried out. The accuracy of the scale shows that each indicator formulated has the same basic factor. That the question items are able to measure the construct being measured, with the item value having a correlation above 0.50

- Reliability Test

The value of the reliability test is generated with the value of the composite reliability coefficient Variable dynamic capability-sensing (DCS) of 0.831 , dynamic capability-seizing (DCSZ) of 0.831 , dynamic capability-reconfiguring (DCR) of 0.831 , environmental dynamics during the Covid-19 pandemic (EDC) of 0.831 and sustainable tourism performance (SP) of 0.831 , so that the value is above 0.7 as a condition for acceptance of composite reliability testing, while for The internal consistency reliability value uses the coefficient criteria Cronbach alpha above 0.60 , so that the accuracy of the questionnaire reliability measurement scale for all factors has met the consistency internal reliability according to the opinion of [24]

\subsection{Hypothesis Model Fit Index Testing}

The results of the Model Fit Index test showed that the model with 10 test indices to determine the index and suitability of the relationship between latent variables and their assumptions, most of the results have met the rule of thumb. All criteria are good and ideal index so it can be concluded that the model of the relationship between latent variables is fit or suitable. 


\subsection{Model Estimation Testing and Path}

Analysis This analysis is used to determine the effect of dynamic capability-sensing (DCS), dynamic capability-seizing (DCSZ), dynamic variables. capability-reconfiguring (DCR) on sustainable tourism performance (SP). The data obtained were analyzed using warpPLS 5.0. In this study, there is a test that shows the direct effect estimation, the following results of the total effect test are presented in the following figure:

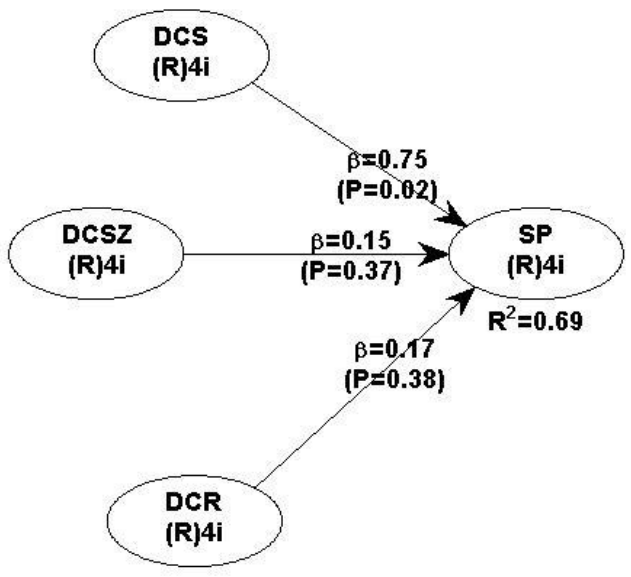

Description: dynamic capability-sensing (DCS), dynamic capability-seizing (DCSZ), dynamic capability-reconfiguring (DCR), and sustainable tourism performance (SP)

Based on the results of the above analysis, a model of sustainable tourism performance equation $(\mathrm{SP})=0.750 \mathrm{DCS}+0.148 \mathrm{DCSZ}+0.173 \mathrm{DCR}$ can be formulated.

The coefficient of dynamic capability-sensing (DCS), of 0.750 and the coefficient of dynamic capability-seizing (DCSZ) of 0.148 and dynamic capability-reconfiguring (DCR) of 0.173 has a positive direction towards sustainable tourism performance (SP), so that if the dynamic capability of the managers is getting involved in village tourism means that it has a strong and positive influence on the variable of sustainable tourism performance (SP).

\subsection{Hypothesis Testing}

To test the hypothesis in this study, multivariate analysis was used using the WarpPLS program. Hypothesis testing was carried out by comparing the significance probability value $(p / \alpha)$ which was determined at 0.05 . If the $p$-value is greater than the probability value, the hypothesis is rejected, and if the $p$-value is significantly smaller than $\alpha$, then the hypothesis can be accepted.

FIGURE 1. Estimated Value Testing

TABLE 1. Hypothesis Testing

\begin{tabular}{|l|c|l|l|l|l|}
\hline No & Hypothesis & \multicolumn{1}{|c|}{ Item } & $\begin{array}{c}\boldsymbol{\beta} / \\
\text { Coefficient } \\
\text { Path }\end{array}$ & $\begin{array}{c}\text { P- } \\
\text { Value }\end{array}$ & \multicolumn{1}{|c|}{ Information } \\
\hline $\mathbf{1}$ & $\mathrm{H}_{1}$ & $\begin{array}{l}\text { Dynamic capability-sensing (DCS } \rightarrow \text { Sustainable } \\
\text { tourism performance (SP }\end{array}$ & 0.750 & 0.019 & Support Hypothesis \\
\hline $\mathbf{2}$ & $\mathrm{H}_{2}$ & $\begin{array}{l}\text { Dynamic capability-seizing (DCSZ) } \rightarrow \\
\text { Performance sustainable tourism (SP }\end{array}$ & 0148 & 0374 & $\begin{array}{l}\text { Does Not Support the } \\
\text { hypothesis }\end{array}$ \\
\hline $\mathbf{3}$ & $\mathrm{H}_{3}$ & $\begin{array}{l}\text { Dynamic capability-reconfiguring (DCR) } \rightarrow \\
\text { performance sustainable tourism (SP) }\end{array}$ & 0173 & 0378 & $\begin{array}{l}\text { Does Not Support } \\
\text { hypothetical }\end{array}$ \\
\hline
\end{tabular}

\subsection{Discussion}

With the results obtained then the discussion for each result based on hypothesis testing What has been done can be discussed as follows:

- The variable dynamic capability of the sensing dimension (DCS) has an effect on sustainable tourism performance (SP), the test results show that the coefficient of direct effect of dynamic capability on sensing dimension (DCS) on sustainable tourism performance (SP) is 0.750 This means that the dynamic capability sensing dimension (DCS) variable has a positive relationship with the sustainable tourism performance variable (SP), this result provides information that the better the dynamic capability sensing dimension (DCS), such as managers who pay attention to the environment to identify tourism development opportunities, are ra periodically reviews the possible impact of changes in the village tourism business environment on visitors, reviews the possible impact of changes in the village tourism business environment on visitors, and implements ideas for village tourism and improves existing mutually supportive efforts for village tourism to be able to create The performance of sustainable 
tourism, the higher it is, such as the sustainability of tourist satisfaction on village tourism, the sustainability of profits is an important part of developing village tourism, the sustainability of the economic impact of the community and the overall sustainability of the impact in developing village tourism. Thus these results are supported by a significance value for the dynamic capability dimension sensing (DCS) variable of $0.019<0.05$, this indicates that there is an effect of dynamic capability sensing dimension (DCS) with sustainable tourism performance (SP). The results of this study support previous studies that have been conducted which provide the same research results as research by [16], [17], [25] who say that the dynamic capability of the sensing dimension has an influence on tourism performance. Sustainable (SP)

- The dynamic capability dimension seizing (DCSZ) variable has an effect on sustainable tourism performance (SP), the test results show that the coefficient of direct influence of dynamic capability dimension seizing (DCSZ) on sustainable tourism performance (SP) is 0.416 , meaning the dynamic capability variable The seizing dimension (DCSZ) has a positive relationship with the variable on sustainable tourism performance (SP), this result provides information that the better the dynamic capability of the seizing dimension (DCSZ), as it can quickly relate to new knowledge from outside, new information can be used for management. village tourism business, capable of $\mathrm{m}$ he changes knowledge of new technology into new processes and product / business innovation, the latest information obtained leads to the development of new businesses in village tourism businesses, the higher the performance of sustainable tourism (SP) with sustainable tourist satisfaction on village tourism, sustainability of profits is an important part of its development. village tourism, the sustainability of the economic impact of community members and the overall sustainability of the impact in the development of village tourism. However, this result is not supported by the significance value for the dynamic capability dimension seizing (DCSZ) style variable which is only $0.374>0.05$, this indicates that there is no effect of dynamic capability dimension seizing (DCSZ) with sustainable tourism performance (SP). The results of this study are in contrast to research which provides different research results from research by [16], [17], [25] which states that the dynamic capability of the seizing dimension has a positive effect on sustainable tourism performance (SP )

- Variable dynamic capability dimension of reconfiguring (DCR) effect on the performance of sustainable tourism (SP), the test results showed that the coefficient of the direct effect of dynamic capability dimension of reconfiguring (DCR) on the performance of sustainable tourism (SP) is equal to 0.256 , meaning that the variable dynamic capability dimension of reconfiguring ( DCR) has a positive relationship with the variable of sustainable tourism performance (SP), this result provides information that the higher the dynamic capability of the reconfiguring dimension (DCR), such as being able to allocate human resources clearly, responding quickly to changes in visitor desires, responding quickly te If other tourism is doing and communicating efficiently and effectively with team members, the higher the performance of sustainable tourism (SP) is produced, such as the sustainability of tourist satisfaction on village tourism, sustainability of profits is an important part of developing village tourism, sustainability of the economic impact of residents community and Overall sustainability impact in rural tourism development. However, this result is not supported by the significance value for the dynamic capability dimension seizing (DCSZ) style variable which is only $0.374>0.05$, this indicates that there is no effect of dynamic capability dimension seizing (DCSZ) with sustainable tourism performance (SP). The results of this study are contrary to the research conducted which provides different research results from the research of [16], [17], [25] who say that the dynamic capability of the reconfiguring dimension has a positive effect on sustainable tourism performance ( SP). However, the results of this study are consistent with [18] specifically reconfiguring relationships with performance has no effect on performance.

\section{CONCLUSIONS}

Referring to the research results and interpretation of the results and based on the research objectives, can be presented the conclusions following as follows: 1) dynamic capability sensing dimensions affect sustainable tourism performance; 2) dynamic capability seizing dimensions have no effect on sustainable tourism performance and 3) dynamic capability reconfiguring dimensions do not affect sustainable tourism performance. With the impact of 
the dynamic capability of the sensing dimension on the performance of sustainable village tourism, the manager increases the dynamic capabilities of the organization such as the ability to identify tourism development opportunities, periodically reviewing the possible impact of changes in the village tourism business environment on visitors, reviewing the possible impact of changes in the tourism business environment. village towards visitors, and implement ideas for village tourism as well as increase efforts to mutually support existing village tourism such as tourism product diversification. This study has limitations when collecting data during the Covid-19 pandemic so it is not optimal, so this study uses a PLS analysis tool which is possible for small data analysis, even though the resampling process has been carried out, so that in the future it can increase samples from various managers. wider village tourism. Then future research can add factors that come from external organizations because the tourism business is strongly influenced by environmental dynamics, such as technology [26], changes in the Covid-19 pandemic situation, tourist destinations cannot carry out their activities normally, as well as destination management must be able to prioritize the value that tourists will get when visiting a destination[27]

\section{REFERENCES}

[1] https://www. merdeka. com/. > U. (https://www.merdeka.com/uang/) and Data, "Data BPS: Indonesia Miliki 1.734 Desa Wisata," Merdeka.com, 2018.

[2] F. Aref and S. S. Gill, "Rural Tourism Development through Rural Cooperatives," Nat. Sci., vol. 7, no. 31, 2009.

[3] V. Nair, U. T. Munikrishnan, S. D. Rajaratnam, and N. King, "Redefining Rural Tourism in Malaysia: A Conceptual Perspective," Asia Pacific J. Tour. Res., vol. 20, no. 3, pp. 314-337, 2015.

[4] M. R. Díaz and T. F. Espino-Rodríguez, "Determining the sustainability factors and performance of a tourism destination from the stakeholders' perspective," Sustain., vol. 8, no. 9, 2016.

[5] R. J. Pinem, D. Purbawati, A. Srifitriani, S. Wahyoedi, and Sukaris, "Green companies and the millennial generation as the spearhead of the environment," Int. J. Innov. Creat. Chang., vol. 8, no. 2, pp. 106-115, 2019.

[6] M. Haseeb, H. I. Hussain, B. Ślusarczyk, and K. Jermsittiparsert, "Industry 4.0: A solution towards technology challenges of sustainable business performance," Soc. Sci., vol. 8, no. 5, 2019.

[7] Z. Arifin and Frmanzah, "The Effect of Dynamic Capability to Technology Adoption and its Determinant Factors for Improving Firm's Performance; Toward a Conceptual Model," Procedia - Soc. Behav. Sci., vol. 207, pp. 786-796, 2015.

[8] M. F. Hasegan, S. S. Nudurupati, and S. J. Childe, "Predicting performance - a dynamic capability view," Int. J. Oper. Prod. Manag., vol. 38, no. 11, pp. 21922213, 2018

[9] R. Torres, A. Sidorova, and M. C. Jones, "Enabling firm performance through business intelligence and analytics: A dynamic capabilities perspective," Inf. Manag., vol. 55, no. 7, pp. 822-839, 2018.

[10] A. R. W. Takahashi, S. Bulgacov, M. M. Giacomini, and C. B. dos Santos, "Dynamic capabilities, political external relationship, educational technology capability and firm performance," Int. Bus. Manag., vol. 10, no. 5, pp. 652-658, 2016.

[11] Angga Indrawan, "Membangun Pariwisata Berkelanjutan," Republika, no. November, pp. 9-12, 2017.

[12] https://disbudparpora.ponorogo.go.id/, "Desa Wisata , Konsep Pariwisata Berkelanjutan Berbasis Pemberdayaan Masyarakat," pp. 1-7, 2020.

[13] A. R. P. Girsang, D. I. Rinawati, and D. Nurkertamanda, "Usulan Strategi Pengembangan Wisata Yang Berkelanjutan Di Bukit Cinta Rawa Pening Dengan Menggunakan Swot Analysis Dan Pendekatan Analytical Network Process (ANP)," Ind. Eng. Online J., vol. 8, no. 1, p. , 2019.

[14] S. Franzoni, "Measuring the sustainability performance of the tourism sector," Tour. Manag. Perspect., vol. 16, pp. 22-27, 2015.

[15] R. Wilden, S. P. Gudergan, B. B. Nielsen, and I. Lings, "Dynamic Capabilities and Performance: Strategy, Structure and Environment," Long Range Plann., vol. 46, no. 1-2, pp. 72-96, 2013.

[16] J. Abbas, S. Raza, M. Nurunnabi, M. S. Minai, and S. Bano, "The impact of entrepreneurial business networks on firms' performance through a mediating role of dynamic capabilities," Sustain., vol. 11, no. $11,2019$. 
[17] T. O. Nyachanchu, J. Chepkwony, and R. Bonuke, "Role of Dynamic Capabilities in the Performance of Manufacturing Firms in Nairobi County, Kenya," Eur. Sci. Journal, ESJ, vol. 13, no. 31, p. 438, 2017.

[18] Y. Lin and L. Y. Wu, "Exploring the role of dynamic capabilities in firm performance under the resource-based view framework," J. Bus. Res., vol. 67, no. 3, pp. 407-413, 2014.

[19] D. J. Teece, G. Pisano, and A. Shuen, "Dynamic capabilities and strategic management: organizing for innovation and growth," Strateg. Manag. J., vol. 18, no. 7, pp. 509-533, 1997.

[20] D. J. Teece, "Explicating Dynamic Capabilities: The Nature And Microfoundations Of (Sustainable) Enterprise Performance," Strateg. Manag. J., vol. 28, no. Juni 2007, pp. 1319-1350, 2007.

[21] A. Jantunen, A. Tarkiainen, S. Chari, and P. Oghazi, "Dynamic capabilities, operational changes, and performance outcomes in the media industry," J. Bus. Res., vol. 89, no. January, pp. 251-257, 2018.

[22] S. Fainshmidt and M. L. Frazier, "What Facilitates Dynamic Capabilities? The Role of Organizational Climate for Trust," Long Range Plann., vol. 50, no. 5, pp. 550-566, 2017.

[23] J. F. Hair, W. C. Black, B. J. Babin, and R. E.anderson, Multivariate Data Analysis. 2014.

[24] J. A. Gliem and R. R. Gliem, "Calculating, Interpreting, and Reporting Cronbach's Alpha Reliability Coefficient for LikertType Scales," Midwest Res. to Pract. Conf. Adult, Contin. Community Educ., 2003.

[25] R. Wilden and S. Gudergan, "Servicedominant orientation, dynamic capabilities and firm performance," J. Serv. Theory Pract., vol. 27, no. 4, pp. 808-832, 2017.

[26] S. Sukaris, S. Hartini, and D. Mardhiyah, "Increasing Electronic Word-of-Mouth Activities through Self-Congruity and Tourist Values," Int. J. Innov. Creat. Chang., vol. 9, no. 10, pp. 162-183, 2019.

[27] S. Hartini, D. Mardhiyah, and Sukaris, "A conceptual framework for relationship between symbolic risk consumption with electronic word of mouth," Opcion, vol. 36, no. Special Edition 26, pp. 1282-1295, 2020. 